\title{
Gastrointestinal Stromal Tumor TNM Finding v8
}

National Cancer Institute

\section{Source}

National Cancer Institute. Gastrointestinal Stromal Tumor TNM Finding v8. NCI

Thesaurus. Code C136749.

A finding about one or more characteristics of gastrointestinal stromal tumor (GIST), following the rules of the TNM AJCC v8 classification system. This classification system does not apply to pediatric GIST, familial GIST (germline mutant KIT or PDGFRA), or syndromic GIST (no AJCC staging system available). (from AJCC 8th Ed.) 